\title{
MEDIAN RAPHE CYST OF PENIS: UNCOMMON BENIGN ENTITY
}

\author{
E. Shyamala1 ${ }^{1}$, Hariprasad K. V², U. Manohar ${ }^{3}$, P. Viswanathan ${ }^{4}$, R. Baskaran ${ }^{5}$
}

\section{HOW TO CITE THIS ARTICLE:}

E. Shyamala, Hariprasad K. V, U. Manohar, P. Viswanathan, R. Baskaran. "Median Raphe Cyst of Penis: Uncommon Benign Entity". Journal of Evolution of Medical and Dental Sciences 2014; Vol. 3, Issue 74,

December 29; Page: 15610-15613, DOI: 10.14260/jemds/2014/4107

\begin{abstract}
Median raphe cyst uncommon entity that can occur in ventral aspects of penis. A patient presented with an enlarging median raphe cyst in the prepuce of the penis is being reported. Excision is usually recommended for a definite histopathological diagnosis and for the prevention of potential risks of malignant transformation.
\end{abstract}

KEYWORDS: Pedunculated lesion of the prepuce of penis, Median raphe cyst of penis.

INTRODUCTION: Median raphe cyst of penis arises usually in young adult. They are located on the ventral aspects of the penis most commonly on the glans. They are solitary and measures only a few millimeters in diameter. ${ }^{1}$ However, they may extend over several centimeters in a linear fashion. It seems that, in some instances, median raphe have been erroneously reported as apocrine cystadenoma of the penis. ${ }^{2,3}$ It is likely that median raphe cyst do not represent a defective closure of the median raphe, but rather the anomalous budding and separation of urethral columnar epithelium from the urethra. ${ }^{4}$

CASE REPORT: A 27 years male presented with swelling / mass in the prepuce of the penis since birth. Initially the swelling was small in size and gradually increase in size. There was no relevant history except for a mass. There is no history of trauma or pain.

On examination, a pedunculated mass of $3 \times 2 \mathrm{~cm}$ size was present in prepuce of the penis, which is soft in consistency and there was no tenderness or fixity. The patient was subjected to circumcision and excised; the cystic mass was sent for histopathology.

\section{PATHOLOGICAL EXAMINATION:}

MACROSCOPY FINDING: The specimen was globular, well capsulated mass of $3 \times 2 \times 1 \mathrm{~cm}$ in diameter which was soft, cystic in nature. On cut section, the predunuclated mass showed a cyst filled with grey white pultaceous material. Wall is of even thickness.

MICROSCOPY FINDING: The cyst is partially lined by low columnar to cuboidal cells, which exhibits pseudostratification; part of the cyst is lined by squamous epithelium probably due to squamous metaplasia of the pseudostratified columnar epithelium.

DISCUSSION: Median raphae cyst is due to embryonal developmental defect occurring in male genitalia. The cyst is seen near glans penis. The lining is pseudostratified columnar epithelium of one to four cells thickness, mimicking the transitional epithelium of the urethra. Some of the epithelial cells have clear cytoplasm, mucin-containing cells are uncommon, and a case lined by ciliated epithelium has been described ${ }^{5}$. The lining of the cyst prove theory that the median raphe cyst, are anomalous budding and separation of urethral columnar epithelium from the urethra. 


\section{CASE REPORT}

CONCLUSION: In conclusion, the swelling may remain asymptomatic unless secondarily infected. Care needs to be taken while performing even minor surgical procedure to avoid this complication. The condition should be treated by complete excision.

\section{EQUIPMENT USED:}

1. Nikon coolpix-8400.

2. X-denotes the power of objective.

3. Stain used-[H\&E].

\section{REFERENCES:}

1. Cole LA, Helvig EB. Mucoid cysts of the penile skin. J urol 1976; 115: 397.

2. Ahmed A, Jones AW. Apocrine cystadenoma. Br J Dermatol 1969; 81: 899.

3. Powel RF, Palmer CH, Smith EB. Apocrine cystadenoma of the penile shaft. Arch Dermatol 1977; 113: 1250.

4. Paslin D. Urethroid cyst. Arch Dermatol 1983; 119: 89.

5. Romani J, Barnadas MA, Miralles J et al. Median raphe cyst of the penis with ciliated cells. J cutan pathol 1995; 22:378.

\section{MACROSCOPIC IMAGES:}

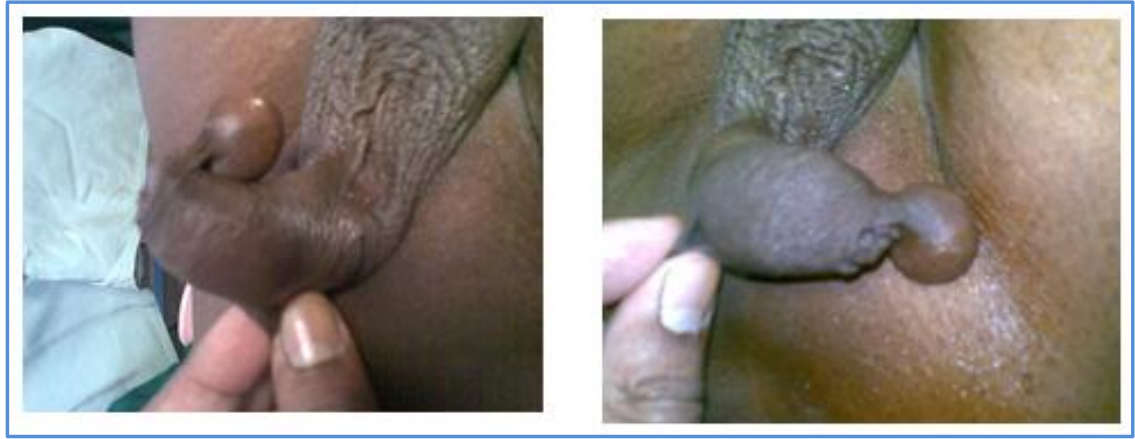

Fig. 1
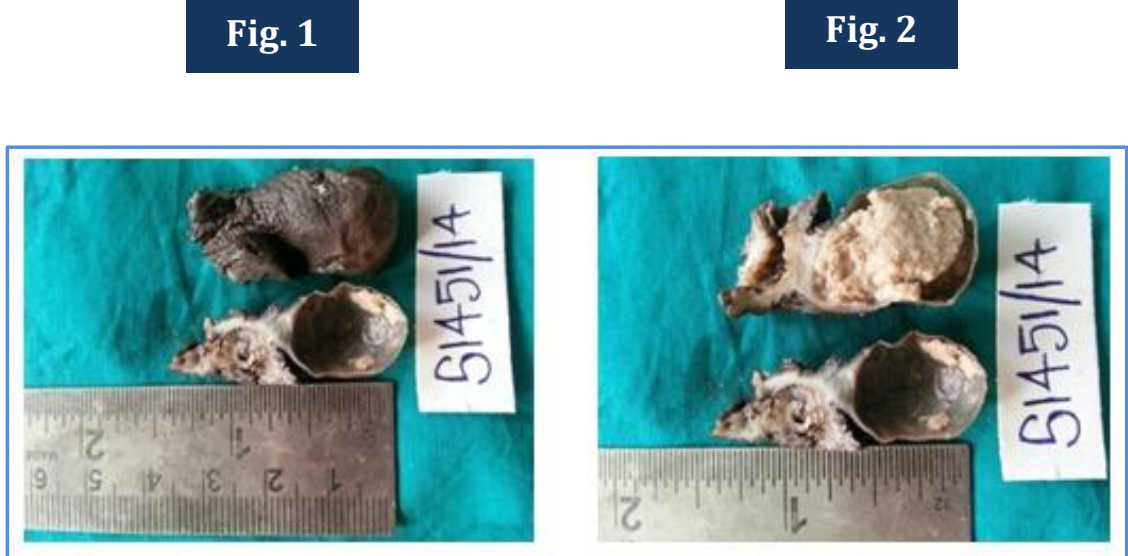

Fig. 3

Fig. 4

Cyst is filled with pultaceous material. 


\section{CASE REPORT}

\section{MICROSCOPIC IMAGES:}

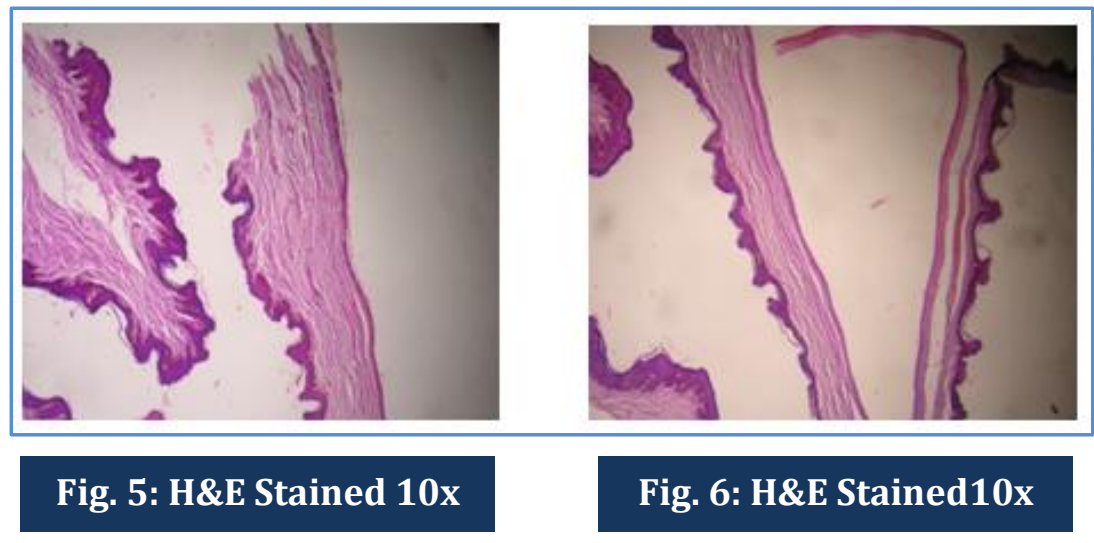

Prepuce with the cyst lining

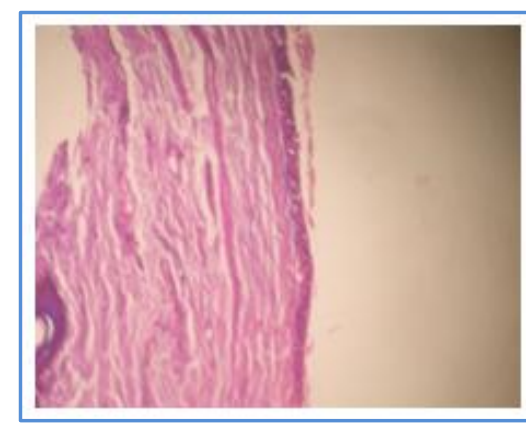

Fig. 7: H\&E Stained 20x

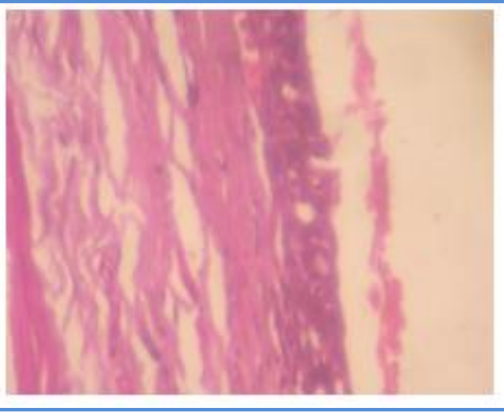

Fig. 8: H\&E Stained 40x

Cyst is lined by pseudo stratified columnar epithelium.

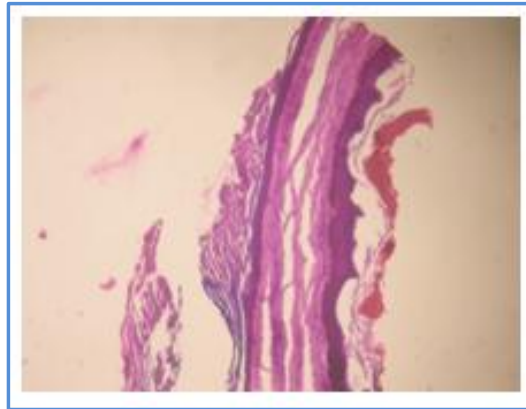

Fig. 9: H\&E Stained 20x

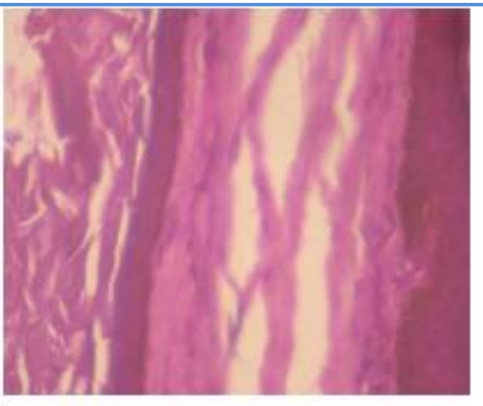

Fig. 10: H\&E Stained 40x

Cyst is filled with flakes of keratin and is lined by squamous epithelium. 


\section{AUTHORS:}

1. E. Shyamala

2. Hariprasad K. V.

3. U. Manohar

4. P. Viswanathan

5. R. Baskaran

\section{PARTICULARS OF CONTRIBUTORS:}

1. $2^{\text {nd }}$ Year Post Graduate, Department of Pathology, Rajah Muthiah Medical College, Annamalai University.

2. $3^{\text {rd }}$ Year Post Graduate, Department of Pathology, Rajah Muthiah Medical College, Annamalai University.

3. Professor, Department of Pathology, Rajah Muthiah Medical College, Annamalai University.

4. Professor \& HOD, Department of Pathology, Rajah Muthiah Medical College, Annamalai University.
5. Professor, Department of Surgery, Rajah Muthiah Medical College, Annamalai University.

\section{NAME ADDRESS EMAIL ID OF THE} CORRESPONDING AUTHOR:

Dr. P. Viswanathan,

Professor \& HOD,

Department of Pathology,

Faculty of Medicine,

Rajah Muthiah Medical College,

Annamalai University,

Annamalai Nagar-608002,

Tamil Nadu, India.

E-mail: drpviswanathan2013@gmail.com

Date of Submission: 05/12/2014.

Date of Peer Review: 06/12/2014.

Date of Acceptance: 18/12/2014.

Date of Publishing: 29/12/2014. 